\title{
Effects of a Consumption Tax Rate Increase on Equity Value: Japanese Firms Experience
}

\author{
Keiichi Kubota and Hitoshi Takehara
}

\begin{abstract}
This paper investigates how firm values change when consumption tax rates increase and corporate tax rates decrease. The computation is based on the residual income valuation model starting from the discounted free cash flow model in which we construct a pro forma financial statements using Arzac's framework. We compute equity values at the individual firm level assuming March 31, 2012 as an evaluation date. We find that an increase in consumption tax rate decreases equity values for a majority of firms, but not necessarily all firms. A corporate tax rate cut helps increase the equity value for a majority of firms. The trade-off relationship of a consumption tax rate hike and a corporate tax rate reduction is subtle, but the suitable mix helps increase equity value of firms overall.
\end{abstract}

Index Terms - Value added tax, corporate tax rate, residual income model.

\section{INTRODUCTION}

Analyses of changes in firm values triggered by changes in consumption tax rates and corporate tax rates provide important implications for regulators and corporate financial managers. In this paper, we employ a deterministic approach at the individual firm level to assess the effects of proposed consumption tax hikes in Japan from the $5 \%$ to $8 \%$, starting in April 2014. We construct pro forma financial statements by Arzac's model [1] and compute equity values of firms based on the residual income model. The paper also explores the effects of corporate tax rate cut associated with a consumption tax rate hike.

An increase in the consumption tax will not decrease firm revenue, if firms can completely transfer the levied amount to consumers and consumption expenditure increases at the same rate of a consumption tax increase. In our computation, as a benchmark case we assume the number of products sold is reduced by the ratio of the current tax rate to the raised tax rate and it is multiplied the sales growth (decrease) parameter. That is, we assume firms face a decrease in sales figures net of

Manuscript received August 30, 2014; revised March 1, 2015. This work was supported in part by Grant-in-Aid for Scientific Research ((A) 25245052 and (C) 24530581) from the Japan Society for the Promotion of Science.

Keiichi Kubota is with the Graduate School of Strategic Management, Chuo University, 1-3-27 Kasuga, Bunkyo-ku, Tokyo 112-8511, Japan (e-mail: kekubota@tamacc.chuo-u.ac.jp).

Hitoshi Takehara is with the Graduate School of Finance, Accounting and Law, Waseda University, 1-4-1 Nihombashi, Chuo-ku, Tokyo 103-0027, Japan (e-mail: takehara@waseda.jp). tax as a baseline case allowing for further increase or decrease in sales figures by the future economic conditions.

According to our computations, we find that the effects of consumption tax rates are less than increased tax rates, owing mainly to sales prospects of firms and their input vs. output structure. This will be somewhat detrimental to the tax authority, but good for firm managers. Moreover, an additional reduction in the corporate tax rate, which has been recently proposed by the Japanese government, will increase equity values for a majority of firms except for those with a large balance of tax loss carry-forward and net deferred tax assets.

Section II proposes the motivation of our study and states the research objectives. Section III formulates the valuation model. Section IV explains the data and reports basic observations. Section V reports the main empirical results, and extends the analysis to the case when there will be hypothetical changes both in corporate tax rates and consumption expenditures. Section VI concludes.

\section{Motivation AND Main PuRPose OF THE StUdy}

The existing literature has rarely explored how changes in consumption tax rates affect firm revenues, and thus firm equity values. In public economics the efficiency and equity issues for consumers and regulators are more of the issue, and most times do not treat effects on firm valuation. Even in corporate finance research domain, in which area the current paper belongs, the main focus of the research is the effects of corporate tax rates and financial income tax rates (see [2]) on equity valuation, and rarely analyzes the effects of consumption tax rates on firm values. In this sense this paper is new in the field.

Hall [3] briefly discusses the effect of consumption tax on stock prices and argues that domestic equity holders suffer capital losses. We believe that is an empirical question, and we explore this query using the Japanese data. Ballard et al. [4] analyzed the incidence of both the corporate and personal income taxes and claim that the consumption tax can reduce both the distortions of the allocations of capital and capital accumulation.

In this paper we mainly focus on the effect on sales growth (decline) by the consumption tax hike and the corporate tax reduction, which leads to either appreciation of depletion of equity value.

The Japanese value added tax was first proposed by the Shoup Mission in 1949 ([5]) and was included in tax code of Japan in 1950 ([6]), but could not be implemented by the opposition from various parties. The first sales tax rate of $3 \%$ was first collected on April 1, 1989 and was raised to 5 
percent on April 1, 1997 (see also [7]). Note also that Japanese financial and tax reporting systems follow the so called uniform reporting system like continental Europe ([8]). However, starting in fiscal year 1999, tax deferral accounts in balance sheets were recorded in consolidated financial statements on the condition that such an accrued amount had a high probability to be reversed in the future. In spite of this new tax timing difference allowance, the Japanese system can still be classified as a uniform reporting system in the sense that depreciation methods, inventory costing, and other major accounting choices have to follow uniform reporting both for tax and financial accounting purposes.

Consumption tax reform has already been proposed by the current government in two stages; from 5\% to $8 \%$ on April 1, 2014 , and $8 \%$ to $10 \%$, most likely on October 1, 2015 and we also analyze the hypothetical cases where consumption tax rates are raised to $15 \%$ and $20 \%$. Furthermore, cases where corporate tax rates are cut an extra $5 \%$ and $10 \%$ are also analyzed simultaneously.

We utilize the discounted free-cash flows model which seems suitable to predict the sales and cost parameters at each firm level. We analyze the effects of tax reform and demonstrate the distributions of equity value changes for each tax parameter value. This study is unique in the public finance literature because we use the equity valuation model from the corporate finance literature at the micro level, and derive an entire picture of tax effects on equity values of all listed firms in Japan.

\section{EQUITY VALUATION MODEL}

Based on the methodology developed in [9] for constructing pro forma financial statements, we first compute free cash flows $(F C F)$ and net income in future fiscal periods up to 10 years. ${ }^{1}$ In order to compute firms' profits, the sales before tax for the current period after a consumption tax rate hike is computed on a before consumption tax base. In the following equation (1) $t v_{0}$ is the previous consumption tax rate, $t v_{1}$ is the new consumption tax rate, $S L S B T_{t-1}$ is the sales in the previous period, and $g_{S L S}$ is the past five year average growth rate of sales. We assume the expected number of the products sold $S L S B T_{t-1} \times g_{S L S}$ decreases by the ratio of the old and new consumption tax rates $\left(1+t v_{0}\right) /\left(1+t v_{1}\right)$, and the sales figure for which consumption tax is added is computed by subtracting the proportion of foreign sales, $\delta_{F O R}$ as in equation (2).

$$
\begin{gathered}
S L S B T_{t}=S L S B T_{t-1} \times g_{S L S} \times\left(1+t v_{0}\right) /\left(1+t v_{1}\right) \\
\text { Sales }_{t}=S L S B T_{t} \times\left(1+\left(1-\delta_{F O R}\right) \times t v_{1}\right)
\end{gathered}
$$

The cost of goods sold is computed by using a fraction of the cost of goods sold to sales before tax $\left(\delta_{C S}\right)$, possible increases (decrease) in wage costs and economic recovery

\footnotetext{
${ }^{1}$ Free cash flow here is defined as Earnings before tax multiplied by (1-effective corporate tax) plus deprecation plus decrease in net working capital minus capital expenditures and the realized capital gains and taxes are not included.
}

(stagnation in wages and economic downturn) $\left(\delta_{S T C S}\right)$, and the proportion of cost of goods sold which is subject to the consumption tax $\left(=1-\right.$ labor cost ratio) $\left(t v_{1}-t v_{0}\right)$, which will all be affected by a hike in the consumption tax rate.

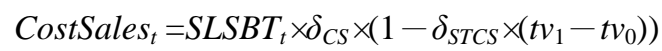

Other expense items and the discrete-time evolutions of balance sheet items are basically either one of a function of the growth rate of sales $g_{S L S}$, like in (4), the constant ratio of the sales $\delta_{A R}$ as in (5), or the constant ratio of the aggregate balance sheet item $\delta_{S T D}$ as in (6).

$$
\text { TotalDebt }_{t}=\text { TotalDebt }_{t-1} \times g_{S L S}
$$

$$
\begin{aligned}
& \text { AccountsReceivable }_{t}=S L S B T_{t} \times \delta_{A R} \\
& \text { ShorTermDebt }_{t}=\text { TotalDebt }_{t} \times \delta_{S T D}
\end{aligned}
$$

Then the EBIT (earnings before interest and taxes) can be computed as follows:

$$
E B I T_{t}=\text { GrossProfit } t_{t}-S G A_{t}-d \times\left(t v_{1}-t v_{0}\right)
$$

where $d=\left(1-\delta_{C S} \delta_{S T C S}-\delta_{S G A} \delta_{S T S G A}\right)$.

In equation (7) the first term is Gross Profit, which is computed by subtracting (3) from (2). $S G A_{t}$ is administrative and selling expenses where the current consumption tax rate of $5 \%$ is assumed.

We then adjust for the change in value-added tax calculations as follows. In (7), $\delta_{C S}$ is the ratio of production costs to sales net of tax (SLSBT), and $\delta_{S G A}$ is the ratio of the administrative and selling expenses to sales (SLSBT). To adjust for these costs, which are not subject to value-added tax (i.e., material cost, advertisement cost, etc.), we do the following computations. First, $\delta_{S T C S}$ denotes the portion of production costs not subject to consumption tax, and $\delta_{S T S G A}$ denotes the portion of the administrative and selling expense production costs not subject to consumption tax. Thus, (1$\left.\delta_{C S} \times \delta_{S T C S}-\delta_{S G A} \times \delta_{S T S G A}\right)$ shows the portion which is subject to consumption tax (value-added tax), and to this term the change in consumption tax rate $\left(t v_{1}-t v_{0}\right)$ is multiplied and applied only to domestic sales $\left(1-\delta_{F O R}\right)$. Finally, these are all multiplied by the sales before tax, $S L S B T_{t}$.

Starting from this future free cash flow model, we compute residual income $(R I)$ by Ohlson (1995) to derive the equity value of firms. In this valuation stage we assume residual income will decay by $70 \%$ every year. From the total value of the firm $F V$, we further compute equity value of the firm $E V$, based on the residual income model (RIM) model as stated above, where $N I_{t}$ is the net income after tax, $B V_{t}$ is the accounting book value of the equity, and $r_{E}$ is the cost of equity. We assume that after ten years the residual income of the firm follows an autoregressive process decaying at rate $\eta$.

Using the Edwards-Bell-Ohlson residual income model [10], the equity value of the firm $E V$ is given by

$$
E V_{0}=B V_{0}+\sum_{t=1}^{10} \frac{N I_{t}-r_{E} B V_{t-1}}{\left(1+r_{E}\right)^{t}}+\frac{N I_{11}-r_{E} B V_{10}}{\left(1+r_{E}-\eta\right)\left(1+r_{E}\right)^{10}}
$$




\section{EMPIRICAL ASSESSMENT OF SALES TAX EFFECTS}

We obtain observations of 1,410 firms across 29 industries based on 33 industry classifications of the Tokyo Stock Exchange, excluding financial firms.

Table I reports the results on change in the equity value of firms given by equation (8) triggered by the increase in consumption tax rates from the current $5 \%$ to 10,15 , and $20 \%$, respectively. In this table, 'EVR' denotes the ratio of the equity value of the firm after the sales tax hike to the value before, and EVR larger (smaller) than 1 means the value appreciates (depreciates). We report the EVR of the firm after the tax rate hike to the equity value under the current consumption tax rate. In Table I, $85.704 \%$ of the sample shows a decrease in the equity value of firms between ratios 0.95 and 1 . We also find $11.054 \%$ of the firms experience an increase in total value between ratios 1 and 1.05 . When the consumption tax rate is increased from $8 \%$ to $10 \%$, the distribution does not change drastically, which, according to our view, provides important implications to regulators. However, when the sale tax rate is further increased to $15 \%$, we find that $17.244 \%$ of firms experience value depreciation between ratios 0.9 and 0.95 . When the tax rate is raised further to $20 \%, 33.088 \%$ of firms experience a decrease in the ratio between 0.9 and 0.95 .

TABLE I: IMPACT OF CHANGE IN CONSUMPTION TAX RATE ON VALUATION

\begin{tabular}{lrrrr}
\hline & $t_{v}=8 \%$ & $t_{v}=10 \%$ & $t_{v}=15 \%$ & $t_{v}=20 \%$ \\
\hline \hline $\mathrm{EVR}<0.7$ & 0.000 & 0.295 & 0.958 & 1.548 \\
$0.7 \leqq \mathrm{EVR}<0.75$ & 0.000 & 0.221 & 0.368 & 0.442 \\
$0.75 \leqq \mathrm{EVR}<0.8$ & 0.295 & 0.221 & 0.442 & 0.368 \\
$0.8 \leqq \mathrm{EVR}<0.85$ & 0.221 & 0.516 & 0.590 & 0.958 \\
$0.85 \leqq \mathrm{EVR}<0.9$ & 0.516 & 0.590 & 1.253 & 4.790 \\
$0.9 \leqq \mathrm{EVR}<0.95$ & 1.326 & 2.063 & 17.244 & 33.088 \\
$0.95 \leqq \mathrm{EVR}<1$ & 85.704 & 84.156 & 67.207 & 46.942 \\
\hline $1 \leqq \mathrm{EVR}<1.05$ & 11.054 & 10.538 & 9.727 & 9.138 \\
$1.05 \leqq \mathrm{EVR}<1.1$ & 0.442 & 0.737 & 0.811 & 0.884 \\
$1.1 \leqq \mathrm{EVR}<1.15$ & 0.074 & 0.221 & 0.516 & 0.516 \\
$1.15 \leqq \mathrm{EVR}<1.2$ & 0.000 & 0.000 & 0.221 & 0.295 \\
$1.2 \leqq \mathrm{EVR}<1.25$ & 0.074 & 0.074 & 0.221 & 0.295 \\
$1.25 \leqq \mathrm{EVR}<1.3$ & 0.074 & 0.000 & 0.000 & 0.074 \\
$1.3 \leqq \mathrm{EVR}<1.35$ & 0.000 & 0.074 & 0.000 & 0.147 \\
$1.35 \leqq \mathrm{EVR}<1.4$ & 0.000 & 0.000 & 0.000 & 0.074 \\
$1.4<\mathrm{EVR}$ & 0.221 & 0.295 & 0.442 & 0.442 \\
\hline
\end{tabular}

\section{FURTHER ANALYSIS OF CONSUMPTION TAX RATE CHANGES AND CORPORATE TAX RATE CHANGES}

Table II shows the effects of the effective corporate tax rate reduction from the current rate of $35.51 \%$ after to $30.15 \%$ after the proposed 5\% reduction, and our hypothetical $24.81 \%$, respectively.

The results reveal that effects of lifting the surcharge were not enough to cancel out adverse effects of a consumption tax rate hike to $8 \%$, judging by the percentage number of $85.326 \%$ of equity value ratio changes between 0.95 and 1 . However, a $5 \%$ corporate tax rate reduction can cancel out adverse effects of a consumption tax rate hike for a majority of firms $(61.409 \%$ between 1 and 1.05 vs. $33.896 \%$ between 0.95 and 1). A further decrease will result and $72 \%$ $(=58.254+13.353)$ of firms will experience equity value appreciation of less than $10 \%$ (between 1 and 1.1). The detrimental effect is also limited to $24.505 \%$ of firms $(0.95$ and 1) compared to $33.896 \%$ when the corporate tax is cut by $5 \%$.

TABLE II: DECREASE IN CORPORATE TAX RATE AND EVR

\begin{tabular}{lrrr}
\hline Corporae Tax Rate $=$ & \multicolumn{1}{c}{$35.51 \%$} & \multicolumn{1}{c}{$30.16 \%$} & \multicolumn{1}{c}{$24.81 \%$} \\
\hline \hline EVR $<0.7$ & 0.293 & 0.734 & 0.734 \\
$0.7 \leqq \mathrm{EVR}<0.75$ & 0.000 & 0.220 & 0.147 \\
$0.75 \leqq \mathrm{EVR}<0.8$ & 0.440 & 0.220 & 0.293 \\
$0.8 \leqq \mathrm{EVR}<0.85$ & 0.220 & 0.367 & 0.367 \\
$0.85 \leqq \mathrm{EVR}<0.9$ & 0.514 & 0.587 & 0.440 \\
$0.9 \leqq \mathrm{EVR}<0.95$ & 1.321 & 1.174 & 1.101 \\
$0.95 \leqq \mathrm{EVR}<1$ & 85.326 & 33.896 & 24.505 \\
\hline $1 \leqq \mathrm{EVR}<1.05$ & 11.005 & 61.409 & 58.254 \\
$1.05 \leqq \mathrm{EVR}<1.1$ & 0.440 & 0.734 & 13.353 \\
$1.1 \leqq \mathrm{EVR}<1.15$ & 0.073 & 0.220 & 0.367 \\
$1.15 \leqq \mathrm{EVR}<1.2$ & 0.000 & 0.000 & 0.000 \\
$1.2 \leqq \mathrm{EVR}<1.25$ & 0.073 & 0.073 & 0.073 \\
$1.25 \leqq \mathrm{EVR}<1.3$ & 0.073 & 0.000 & 0.000 \\
$1.3 \leqq \mathrm{EVR}<1.35$ & 0.000 & 0.073 & 0.073 \\
$1.35 \leqq \mathrm{EVR}<1.4$ & 0.000 & 0.000 & 0.000 \\
$1.4<\mathrm{EVR}$ & 0.220 & 0.293 & 0.293 \\
\hline
\end{tabular}

TABLE III: SENSITIVITY ANALYSIS OF CONSUMPTION TAX RATE CHANGES AND CORPORATE TAX RATE CHANGE

\begin{tabular}{cllccc}
\hline Corporate & \multicolumn{5}{c}{ Consumption Tax Rate } \\
\cline { 2 - 6 } Tax Rate & $5 \%$ & $8 \%$ & $10 \%$ & $15 \%$ & $20 \%$ \\
\hline \hline $40.86 \%$ & 0.985 & 0.974 & 0.968 & 0.954 & 0.941 \\
$35.51 \%$ & $\mathbf{1 . 0 0 0}$ & 0.990 & 0.984 & 0.970 & 0.956 \\
$30.16 \%$ & 1.015 & 1.007 & 1.003 & 0.990 & 0.974 \\
$24.81 \%$ & 1.029 & 1.021 & 1.015 & 1.005 & 0.995 \\
\hline
\end{tabular}

Table III reports the mixed effects of a hypothetical consumption tax rate change to $10 \%$ (predicted for April 2015), 15\% (some U.S. state and European country levels), and $20 \%$ (European level) accompanying corporate tax rate increases or reductions.

When the corporate tax rate returns to the level of $40.86 \%$ which is before 2012, the numbers (median value for all reported samples) are all below 1 . When consumption tax rates are changed to $15 \%$ to $20 \%$, the numbers are 0.954 and 0.941, respectively, and the median firm experiences an equity value depreciation of 5 to $6 \%$. This tendency does not drastically change even when the tax rate is reduced to $35.51 \%$ (the benchmark case in our analysis) after the lifting of the East Japan Earthquake Surcharge Tax. Again, the effect of this surcharge tax is small.

However, when the corporate tax is reduced $5 \%$ to $30.16 \%$ and the consumption tax rate is increased to $10 \%$, the median firm will not suffer. Although we analyze the whole distributions of the equity value changes, we take an example of the change in median firm as a representative firm. Because the distributions are not symmetrical, the choice of median is more appropriate than means.

We believe this is a very important finding and has implications for regulators and corporate financial managers. In the case when there is a further $5 \%$ reduction in the corporate tax rate to $24.81 \%$, we find there are detrimental effects from a consumption tax rate hike (0.995 in the table) only when the rate is increased to a hypothetical $20 \%$ (European level). We think this is an illuminating finding. 
Overall, our micro approach of analyzing changes in firm values owing to a consumption tax rate hike and corporate tax rate changes revealed two new important findings. The role of firm cost structure and sales growth rate is one, and the issue of a consumption tax rate hike with a simultaneous corporate tax rate reduction is another.

\section{CONCLUSION}

This paper investigated how firm equity values change by an increase in the consumption tax rate recently proposed by the Japanese government, and conducted the analysis by applying plausible alternative tax rate input values including the corporate tax rate. The computation is based on the residual income valuation model by Ohlson starting from the discounted free cash flow (DCF) model, both applied at the individual firm level. For this purpose we interpolate the future cash flow stream of firms from pro forma financial statements.

We found that an increase in consumption tax rates decrease equity values for a majority of firms in Japan as of March $31^{\text {st }}, 2012$, but not necessarily all firms, and the sum of sales and corporate tax revenues increases for the central government. In addition, the additional corporate tax rate cut helps increase the equity value for a majority of firms. The knife edge relationship of a consumption tax rate hike and a corporate tax rate reduction is subtle, but the policy mix helps increase equity value of firms overall. Policy implications from this study are important for both tax regulators and corporate financial managers. A further extension of this study by introducing the plausible production functions and the industry-wise demand condition shifts are subject to our future research.

\section{REFERENCES}

[1] E. R. Arzac, Valuation of Mergers, Buyouts, and Restructuring, John Wiley \& Sons: Danvers, MA, 2008.

[2] J. R. Graham, "Debt and the marginal tax rate," Journal of Financial Economics, vol. 41, pp. 41-74, 1996.

[3] R. Hall, "The effects of tax reform on prices and asset valuation," Tax Policy and the Economy, vol. 10, pp. 71-88, 1996.
[4] C. L. Ballard, J. K. Scholz, and J. B. Shoven, "The value-added tax: A general equilibrium look at its efficiency and incidence," in The Effects of Taxation on Capital Accumulation, M. Feldstein, Ed. The University of Chicago Press: Chicago, IL, 1987 pp. 445-474.

[5] M. Bronfenbrenner, "The Japanese value-added sales tax," National Tax Journal, vol. 3, pp. 298-314, 1950.

[6] W. E. Brownlee, E. Ide, and Y. Fukagari, The Political Economy of Transnational Tax Reform: The Shoup Mission to Japan in Historical Context, Cambridge University Press: Cambridge, UK, 2013, pp. $140-141$.

[7] J. B. Shoven, "The Japanese tax reform and the effective rate of tax on Japanese corporate investment," Tax Policy and the Economy, vol. 3, pp. $97-115,1989$.

[8] J. G. Cummins, T. S. Harris, and K. A. Hassett, "Accounting standards, information flow, and firm investment behavior," in The Effects of Taxation on Multinational Corporations, M. Feldstein, J. R. Hines, and R. G. Hubbard, Eds. University of Chicago Press: Chicago, IL. 1995.

[9] K. Kubota and H. Takehara, "Effects of a sales tax increase on firm valuation: Free cash flow approach to individual firm data," Working Paper, Chuo University, 2014.

[10] J. Ohlson, "Earnings, book values, and dividends in equity valuation," Contemporary Accounting Research, vol. 11, pp. 661-687, 1995.

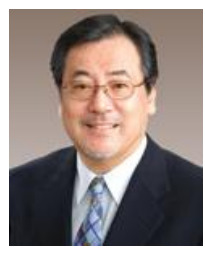

Keiichi Kubota received the BA degree in management at International Christian University, Japan in 1971, the master degree of economics at Graduate School of Economics at University of Tokyo, Japan in 1973, the master degree of science in finance at Graduate School of Industrial Administration, US in 1976, and the PhD degree in economics at Graduate School of Economics at Osaka University, Japan in1995. His major research area is finance, accounting, and public finance.

$\mathrm{He}$ is currently a professor of finance at Graduate School of Strategic Management, Chuo University and holds professor emeritus at Musashi University.

Dr. Kubota is a member of American Finance Association, American Accounting Association, and is a board member for Japan Finance Association and Nippon Finance Association.

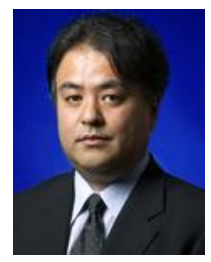

Hitoshi Takehara received his BA degree in socio-economic planning in 1986, the master degree in socio-economic planning in 1989 , and the $\mathrm{PhD}$ degree in management science and engineering in 1993 from University of Tsukuba, Japan.

$\mathrm{He}$ is currently a professor of finance at Graduate School of Finance, Accounting and Law, Waseda University in Japan. His research interests are empirical studies on asset pricing models, portfolio management, and equity valuation. 